\title{
Poema cósmico, de Erasmus \\ Darwin (1731-1802) - avô de Charles Darwin
}

SERGIO MASCARENHAS ${ }^{I}$

Versão livre (Feita no repente...)

Navegai estrela navegai!

Em vossa juvenil primavera exultai

Marcai com curvas brilhantes,

Do tempo os passos

Incessantes.

Cada vez mais e mais perto

Vossas órbitas são encontro certo.

Estrelas sois flores do céu

Mas ao tempo deveis ceder

Frágeis como vossas irmãs

Do campo ao fenecer!

Estrela após estrela se chocando

Sóis dentro sóis se estilhaçando!

E morte, trevas, caos,

Tudo consomem

Sem forma ou função por

Quais se somem!

Mas natureza imortal

Recobra asas da pira funerária

E voa e volta da morte

Temporária!

Roll on, ye Stars! exult in youthful prime, Mark with bright curves the printless steps of Time; Near and more near your beamy cars approach, And lessening orbs on lessening orbs encroach; - Flowers of the sky! ye too to age must yield, Frail as your silken sisters of the field! Star after star from Heaven's high arch shall rush, Suns sink on suns, and systems systems crush, Headlong, extinct, to one dark center fall, And Death and Night and Chaos mingle all! - Till o'er the wreck, emerging from the storm, Immortal Nature lifts her changeful form, 
Mounts from her funeral pyre on wings of flame, And soars and shines, another and the same.

Sérgio Mascarenhas é físico, coordenador do Instituto de Estudos Avançados da USP em São Carlos, diretor do Programa Internacional de Estudos e Projetos para a América Latina e professor emérito do Instituto de Física de São Carlos-USP.

@ - sergiomascarenhas28@gmail.com

${ }^{\text {I }}$ Instituto de Estudos Avançados, Universidade de São Paulo, São Carlos/São Paulo, Brasil.

Recebido em 25.7.2015 e aceito em 19.8.2015. 